\title{
Antropojenik İklim Değişikliğine Bağlı Deniz Seviyesi Değişiminin Sinop Yarımadası'na Olası Etkileri
}

\author{
Yusuf Mert ÜSTÜN1
}

\begin{abstract}
Özet
Küresel iklim değişikliği; kuraklıklar, seller, fırtınalar gibi bir dizi probleme yol açmaktadır. Öte yandan yükselen sıcaklıklar, Dünya buzul varlığını derinden tehdit etmektedir. Eriyen buzullar, küresel deniz seviyesini hızlı bir şekilde yükseltmekte olduğundan dolayı kıyıdaki alçak alanlar doğrudan, kara içindeki yüksek alanlar ise dolaylı yoldan deniz seviyesindeki yükselişten etkilenecektir. Çalışmada deniz seviyesi yükseliminin Anadolu'nun kuzey ucu olan Sinop Yarımadası üzerindeki olası etkilerinin Coğrafi Bilgi Sistemleri kullanılarak saptanması amaçlanmıştır. Bu amaçla Hükümetlerarası İklim Değişikliği Paneli (IPCC) tarafından hazırlanmış 5. değerlendirme raporundaki tahminler ıșığında, Dijital Yükseklik Verileriyle birlikte üretilmiş topografya haritaları oluşturulmuş ve risk altında kalabilecek alanlar tespit edilmiştir. Bu çalışmalar sonucunda yarımadanın büyük bir bölümünde hâkim olan yüksek kıyıların, yükselecek deniz seviyesinden doğrudan etkilenmeyeceği ancak Sarıkum Gölü ve çevresi gibi kimi alçak alanların deniz tarafından işgal edilmesiyle, hassas ekosistemlerinin tehdit altında kalacağı sonucuna ulaşılmıştır. Ayrıca Sinop şehir merkezinin iç limana bakan kısımları başta olmak üzere, şehrin; tarihsel, ekonomik ve sosyokültürel yapısının zarar görebileceği saptanmıștır. Her ne kadar uzun dönemli bir problem olsa da günümüzde etkilerini yağış değişiklikleri vasıtasıyla derinden hissetmeye başladığımız küresel iklim değişikliğine karşı, hızlı şekilde etkili önlemler alınması gerekmektedir. Bu önlemler çerçevesinde kıyıyı dizginlemeye çalışmak gibi masraflı ve tehlikeli, geçici çözümler yerine temiz ve yenilenebilir enerji kaynaklarına önem verilmesi ve iklim değişikliğine karşı kamuoyunda bilinç oluşturulması önerilmiştir.
\end{abstract}

Anahtar Kelimeler: Küresel İklim Değişikliği, Sinop Yarımadası, Deniz Seviyesi, Antroposen, Sera Gazı

\section{Possible Effects of Sea Level Change Due to Anthropogenic Climate Change on Sinop Peninsula}

\begin{abstract}
Global climate change causes a number of problems such as droughts, floods and storms. On the other hand, rising temperatures seriously threaten the existence of Earth's glaciers. While high areas on land will be indirectly affected, areas which have low altitude will be directly affected by rising sea level due to melting glaciers. The main objective of this research is determining the possible effects of sea level rise on Sinop Peninsula which is the most northern part of Anatolia by using Geographic Information Systems. For this purpose, considering of the estimations in the 5th
\end{abstract}

\footnotetext{
${ }^{1}$ Coğrafya Ögretmenliği Bölümü,, Atatürk Eğitim Fakültesi, Marmara Üniversitesi, İstanbul
} İlgili yazar / Corresponding author: 1yusufmertustun@gmail.com

Bu makaleye atıf yapmak için- To cite this article Üstün Y. M. (2019). Antropojenik İklim Değişikliğine Bağlı Deniz Seviyesi Değişiminin Sinop Yarımadası'na Olası Etkileri. Afet ve Risk Dergisi, 2(2), 64-79. 
Afet ve Risk Dergisi Cilt: 2 Sayl: 2, 2019 (64-79)

evaluation report prepared by the Intergovernmental Panel on Climate Change (IPCC), topography maps produced with Digital Elevation Data was created and areas that could be at risk were determined. As a result of these studies, it has been concluded that the high coastal areas which lie most of the peninsula will not be directly affected by the rising sea level, but that some low areas such as Sarıkum Lake and its surrounding areas will be directly occupied by the sea and their sensitive ecosystems will be seriously threatened. Also, it was determined that historical, economic and sociocultural structure of the Sinop city center -especially the parts facing the inner harbor- will be damaged. Although it is a long-term problem, it is necessary to take effective precaution against the global climate change which we are beginning to feel deeply through the changes in precipitation. Within the framework of these precautions, it is proposed to raise public awareness about climate change. Also, it is suggested to give importance to clean and renewable energy sources rather than costly and dangerous, temporary solutions such as trying to control the shore.

Keywords: Global Climate Change, Sinop Peninsula, Sea Level, Anthropocene, Greenhouse Gas

\section{GIRIŞ}

\subsection{Küresel İklim Değgssikliği}

İklim; geniş bir bölgede yaşanan kısa süreli tüm hava olaylarının uzun zaman zarfındaki genel ortalaması şeklinde tanımlanabilir (Erol, 2014). İklim değişikliği ise hâlihazırdaki iklimin, istatistiksel olarak on yıllar - veya daha fazla zaman - içerisinde kayda değer biçimde farklılıklar göstermesi durumudur. Dünya iklimi doğal süreçler vasıtasıyla sürekli olarak bir değişim halindedir ${ }^{2}$ (Türkeş, Sümer ve Çetiner, 2000). Bu değişiklikler doğal süreç ve etmenler vasıtasıyla olabildiği gibi insan etkisiyle de oluşabilir (Türkeş, 2008). Bir küresel iklim değiş̧iminin içerisinde olduğumuzun kanıtları arasında; küresel sıcaklık değişimleri; yağışlar, kasırgalar ve okyanuslardaki değişikler ile deniz seviyesinde yaşanan farklılıklar gösterilebilir (Gautier, 2014).

Geçmişte yaşanmış küresel iklim değişikliklerinin sebebi doğal faaliyetlerdi. İklimi değişikliğine sebep olan bu doğal süreçlere; Güneş aktivitelerinde meydana gelen değişiklikler, orman yangınlarına ve volkanik faaliyetlere bağlı olarak atmosferdeki aerosol birikiminin artması ile gezegenimizin yapı ve yörüngesinde meydana gelen değișimler örnek verilebilir ${ }^{3}$ (Gündoğan, Sayman, Baş, Arıkan ve Özsoy, 2015).

Sanayi devrimi ile birlikte oldukça hızlı bir artış göstermeye başlayan beșeri kaynaklı - başta $\mathrm{CO}_{2}$ olmak üzere - çeşitli gazların salınımının etkisinin artışını tetiklediği "sera etkisi", Güneş’ten

\footnotetext{
2 Kuvaterner'de döngüsel olarak buzul çağlarının yaşandığı Pleistosen devrinde sırasıyla Günz, Mindel, Riss ve Würm buzul dönemleri yaşanmıştır (Şüküroğlu, 2014). Pleistosen'de sıcaklığın ve deniz seviyesinin düşüp buzul bölgelerin yayıldığı bu "soğuk" devirlere "glasiyal", sıcaklık seviyelerinin yükseldiği ve buzulların belli ölçülerde eridiği evrelere de "interglasiyal" denir (Erinç, 2015)

${ }^{3}$ Güneş lekelerinde görülen değişimler; Dünya'ya ulaşan enerji miktarını, “sunspot cycle” olarak adlandırılan güneş lekesi döngülerine paralel bir biçimde değiştirmektedir. Bu değişimler küresel iklimde kimi farklılıklara yol açabilmektedir. Milankoviç döngüsü olarak bilinen Dünya'nın eksen eğikliğindeki değişimler (Rotasyon), Güneş etrafındaki yörüngenin şeklinde meydana gelen değișiklikler (Eksantriklik) ve eksenindeki yalpalanma (Presesyon) gibi hareketler de iklim değișikliğinin belirli döngülerle değișmesine neden olmaktadır. Levha tektoniğinin jeolojik devirler içerisindeki hareketleri, kıtaların konumları başta olmak üzere fiziki yapıdaki farklılașma da iklim değişikliklerine neden olabilmektedir. Kıtaların yer değiștirmesi sonucu buzulların oluşumunda değișiklikler yaşanır, zira buzulların sadece karalarda oluşabilmesinden dolayı, kara kütlelerinin kutuplara yakınlaşmasıyla iklimde bir soğuma görülür. Volkanizma başta olmak üzere atmosfere doğal yoldan salınan veyahut meteor düşmesi sonucu atmosferin yapısını değişmeler de iklimde değişikliklere yol açabilmektedir. Bu açıdan verilebilecek bir örnek de 1815 yılında günümüz Endonezya'sındaki Tambora Dağı'nın patlamasıyla gerçekleşmiş ve yaşanan bu büyük patlama yazı olmayan yıl olarak bilinen soğuk bir dönemi tetiklemiştir ancak bu durum uzun vadede büyük çaplı bir iklimsel değișime neden olamamıștır. Sayılan bu etmenler doğal yoldan iklim değișimlerine neden olan başlıca faktörlerdir ancak iklimsel değişimler tüm zaman aralıkları için tek bir doğal nedenle açıklanamaz (Gizdeş, 2018; Lutgens, Tarbuck ve Tasa, 2014).

4 "Sera gazları" olarak adlandırılan belli - başlı gazlardan bazıları; karbondioksit $\left(\mathrm{CO}_{2}\right)$, metan $\left(\mathrm{CH}_{4}\right)$, azot protoksit $\left(\mathrm{N}_{2} \mathrm{O}\right)$ ve florlu gazlar (F-gazları) olup önemli miktarını - yaklaşık \%75 - karbondioksit oluşturur (URL 1).
} 
Antropojenik İklim Değișikliğine Bağlı Deniz Seviyesi Değișiminin Sinop Yarımadası'na Olası Etkileri gelen kısa dalga boylu ıșınların yeryüzünden yansıdıktan sonra, sera gazlarının oluşturduğu bir katmana çarparak yeryüzüne doğru tekrar yansımasıdır (Aksay, Ketenoğlu ve Kurt, 2005). Aslında sera etkisi gezegenimizde yaşamı destekleyen en önemli unsurlardandır; gerçekten de çoğunluğu su buharından ve az miktarda karbondioksit, metan ve azot oksitten oluşan bir "battaniye" gibi yeryüzünü ısıtarak yaşamı korur. Sera etkisinin olmaması durumunda $+15^{\circ} \mathrm{C}$ olan dünyanın ortalama sıcaklığının $-18^{\circ} \mathrm{C}$ olacağı hesaplanmıștır, ayrıca sera gazlarının sağladığı örtücü etki olmadan geceleri hava sıcaklığı çok daha düşük olacaktır (URL 2; Korkmaz, 2007; King, 2005). Ancak beşeri faaliyetler bu etkiyi daha da arttırarak küresel iklim değişikliğinin temel nedenini oluşturmaktadır.

Günümüzde vuku bulan hızlı sıcaklık artışında ve küresel iklim değişikliğindeki en önemli antropojenik etkiler kuşkusuz 1880'lerden bu yana geçen süre zarfında dünyamızın hızla sanayileşmesi ve bu süreçte insan nüfusu ile yaşayış biçiminin büyük ölçüde değişiklik göstermesiyle yaşanmıştır. Atmosferimizdeki $\mathrm{CO}_{2}$ miktarı ölçümleriyle birlikte, kullanılan fosil yakıtların oranını ölçmek mümkündür, bu durumun temel sebebi fosil yakıtların yakılması ve orman yangınlarıyla üretilen $\mathrm{CO}_{2}$ 'nin karbon izotopu bileşiminin atmosferin kendi bileşiminde var olan $\mathrm{CO}_{2}$ 'ninkinden farklı olmasıdır. Atmosferik $\mathrm{CO}_{2}$ yoğunluğu en azından 600.000 yılın en yüksek seviyesindedir. $\mathrm{CO}_{2}$ varlığının büyük bir bölümü volkanik faaliyetlerden gelse de antropojenik etki hızlı bir şekilde artmaktadır (Gautier, 2014). Öyle ki fosil yakıt tüketimine bağlı olarak 1751'den beri atmosferimize yaklaşık 400 milyar metrik ton karbon salındı, bu sayının yarısını 1980'li yılların sonundan bu yana atmosferimize salınan $\mathrm{CO}_{2}$ oluşturmaktadır (Boden, Marland ve Andres 2017).

1880’lerden günümüze kadar küresel olarak, yaklaşık $+0.9^{\circ} \mathrm{C}$ lik bir ısınma yaşanmıştır (URL 2). $\mathrm{Bu}+0.9^{\circ} \mathrm{C}^{\prime}$ lik artış oldukça önemli bir değişikliktir, öyle ki son buzul çağından bu yana geçen 20.000 yıllık süreçteki sıcaklık artışı sadece $+4^{\circ}{ }^{\circ}$ 'dir (Woodward, 2015). IPCC'nin 56 Ekim 2018'de yayımladığı yeni rapora göre bu ısınma durumu eğer günümüzdeki oranlarda yükselmeye devam ederse 2030 ila 2052 yılları arasında yaklaşık $+1.5^{\circ} \mathrm{C}^{\prime}$ ye ulaşacaktır. Bu hızlı yükseliş dikkat çekicidir, zira rakamın hızla artışı Dünya'nın ekosistemini derinden etkilemekte ve küresel iklim değişikliğinin "küresel tehdit" boyutuna ulaştığı ortaya çıkmaktadır (Erdoğan, Sağlam, Düzgüneş ve Balık, 2008). Bu küresel tehdit; kuşkusuz küresel iklim değișikliğinin tesiri altındaki en kritik bölgelerden biri olan Akdeniz Havzası ve tabii olarak, bu havzanın bir parçası olan Türkiye'yi de etkilemekte; sıcaklık artışlarına ek olarak orman yangınları, seller, fırtınalar ve yașanan sıcak hava dalgalarıyla kendini göstermektedir. Ayrıca 21. yüzyılın sonlarında küresel iklim değişikliğine paralel olarak ülkemizde 2 ila $6^{\circ} \mathrm{C}$ 'lik bir sıcaklık artışı beklenmektedir (Şen, Bozkurt, Göktürk, Dündar ve Altürk, 2013).

Jeolojik zaman çizelgesinde günümüzü karşılamak için kullanılmaya başlanılan "Antroposen Devri” ile örtüşecek biçimde yaşanan beşeri etkinin atmosferi değiştirmesi sürecinden dolayı günümüzdeki küresel iklim değişikliği “Antropojenik Íklim Değişikliği” olarak adlandırılabilir. Antropojenik iklim değişikliğini geçmişte yaşanmış diğer iklim değişikliklerinden ayıran yeni ve farklı özelliklerinden biri de hızıdır. Antropojenik iklim değişikliğindeki öngörmesi zor, hızlı değişim adapte olmayı güç bir hale getirerek doğal ve beşeri işleyişe büyük zararlar verme potansiyeline sahiptir (Ertek, 2017; Ilık-Bilben, 2018).

Geçmiş dönemlerde yaşanmış iklimsel değişiklikler; tarım, ekonomi, siyaset, sosyal hayat ve yerleşme gibi çeşitli beşeri faaliyetler üzerinde pek çok değişime neden olmuştur. Würm'den sonra yaşamış Ilıman devirde (M.Ö. 8000 ve M.Ö. 7000), günümüzün seyrek nüfuslu kurak alanları,

\footnotetext{
${ }^{5}$ IPCC (Hükümetlerarası İklim Değişikliği Paneli), görevi iklim değişikliği ve politikalarıyla ilgili konularda bilgi değerlendirmesi olan, Dünya Meteoroloji Örgütü (WMO) ve Birleşmiş Milletler Çevre Programı (UNEP) tarafından 1988'de kurulmuş bir örgüttür (Türkeş, Şen, Kurnaz, Madra ve Şahin, 2013).
} 
yerleşmeler kurabilmesine imkân tanıyan bir iklime sahipti. Glasiyal ve interglasiyal dönemler arasındaki insan yaşayış alanın bu büyük çaplı değişimlerine ek olarak, daha küçük çaplı iklimsel değişimlerin etkilerinden bahsetmek yerinde olacaktır. Yaşanan ani kuraklaşma ve ısınmaya binaen Maya uygarlığı, MS. 950 civarında hızlı bir biçimde çökmüştür. Maya uygarlığının yıkılmasına yakın dönemlerde Grönland'a yerleşmeye başlayan Vikingler, 1350'lerden 1800'lere kadar kendini hissettiren küçük buzul çağının başlamasıyla birlikte, bölgede yok olmuştur. Ayrıca bu dönemin başlangıcında, Kuzey Amerika'dan gelen ve Britanya adaları üstünden Avrupa'ya ulaşan ani bir nem dalgasının tetiklediği yüksek boyuttaki yağışlar, beraberinde getirdiği çürümeyle birlikte 10 yıl boyunca tarım ürünü yetiştirilmesinde olumsuz sonuçlara yol açtı. Tarımsal üretimdeki bu ani düşüş büyük kıtlıkları beraberinde getirdi. Avrupa'dan epeyce doğuda bulunan, Çin'deki Huangho -Sarı Nehir-, 1332 yılında peş peşe yaşanmış taşkınlar ile pek çok ölüme neden olmuş, cesetler ve su kirliliği beraberinde vebayı getirmiştir. Bu küçük buzul çağının sonuna gelirken, nüfusu hızla artmış ve tarımsal üretimde büyük oranda patatese bel bağlayan İrlanda Adası'nda, ısınan ve daha nemli bir hal alan iklim, patates küfünün yetişebileceği bir ortama ardından da patates kitlığı olarak bilinen açlığa yol açtı. Bu kıtlık sonucunda ölenlerin yanı sıra ada dışına göç edenlerle beraber İrlanda'da büyük bir nüfus azalması yaşandı. (Özdemir, 2004). Küresek iklim değişikliklerinin farklı yollar vasıtasıyla insan yașamına etkide bulunduğu açıkça görülmektedir.

Sonuçları ve etkileri, yağış değiş̧iklikleri veya orman yangınları gibi çeşitli fenomenler kadar hızlı yaşanmasa da küresel iklim değișikliğine bağlı olarak Dünya genelinde artan hava sıcaklıkları, kutuplardaki buzulları her geçen gün daha da eritmekte ve bu duruma bağlı olarak küresel deniz seviyesi yükselmektedir.

\subsection{Küresel Deniz Seviyesi Değişimi}

Küresel iklim değişikliğine bağlı olarak Dünya genelinde ${ }^{6}$ eriyen, büyük ölçüde kutup bölgeleri ile yüksek dağlık alanlardaki buzul örtüsü, günümüz küresel deniz seviyesini her geçen gün yükseltmektedir ${ }^{7}$. Geçmişte de iklim değişikliğine bağlı küresel deniz seviyesi değişimlerini görmek mümkündür. Pleyistosen buzul dönemlerindeki değişimler, geçmişte yaşanmış küresel deniz seviyesi değișimlerine örnektir. 1.180 ile 0,820 milyon yll önceki zaman aralığında gerçekleşmiş Günz buzul döneminde $20 \mathrm{~m}, 730$ ile 429 bin yll önceki zaman aralığında gerçekleşmiş Mindel buzul döneminde 90 m, 347 ile 248 bin yll önceki zaman aralığında gerçekleşmiş Riss buzul döneminde 110 m, 110.000 ile 10.000 bin yıl önceki zaman aralığında gerçekleşmiş Würm buzul döneminde ise 100 m'lik deniz seviyesi alçalmaları görülmüştür. İklim değişiklikleri doğal olarak gerçekleşmiş ve Dünya'nın jeomorfolojisini büyük ölçüde şekillendiren bir unsurdur. Öyle ki 100 metreyi geçen alçalmaların görüldügü buzul dönemlerinde sığ alanların karaya katıldığı ve kara parçaları arasındaki bazı alanlarda doğal köprüler oluştuğu bilinmektedir. Deniz seviyesinde alçalmanın büyük oranları bulduğu devirlerde; Karadeniz bir göl haline gelmiş, Basra Körfezi karaya dönüşmüş, Güneydoğu Asya'daki adaların bazıları birleşmiş ve Manş denizi kaybolmuştur. Anlaşılacağı üzere küresel iklim değişiklikleri kıyı çizgilerinde ve dolaysıyla jeomorfolojide büyük değişiklikler oluşturan bir olaydır. Verilen örneklerin aksine içinde bulunduğumuz dönemdeki iklim değișimi beșeri faaliyetlerin ön planda olduğu, yine bu

\footnotetext{
6 Dünya üzerindeki kimi bölgeler yerel olarak buz varlığını bir süreliğine arttırabilmektedir. Örneğin Antartika'nın - özellikle doğusunda bulunan - kimi bölümleri kısmi bir büyüme eğilimindedir. Ancak unutulmamalıdır ki genel eğilim erimedir ve bu mahallî artışlar - özellikle Grönland'daki - genel erime trendini terse çevirecek düzeyde değildir (URL 3; URL 4)

7 Deniz seviyesinde değişime neden olabilecek başka sebepler de bulunmaktadır, okyanus çanaklarındaki büyük sıradağların genleșmesine veya büzüșmesine binaen deniz seviyesinin değișmesi bu duruma örnektir. Ancak bu hareketler sonucu olușan deniz seviyesi değişimleri oldukça yavaş gerçekleşmektedir (Ward, 2014). Ayrıca, sterik deniz seviyesi değişimi olarak bilinen su kolonlarındaki sıcaklık değișiminin neden olduğu genleșme ya da büzülme ile deniz suyu yoğunluğunun değișmesine bağlı olarak yaşanan değişim ile atmosfer basıncı veya gelgit olayı da deniz seviyesini etkileyebilmektedir (Yıldız, Demir, Gürdal, Akabalı, Demirkol ve Ayhan, 2003). Araştırmada, küresel iklim değişikliğine bağlı olarak yaşanacak deniz seviyesi değişmelerini incelediğinden buzulların erimesine bağlı deniz seviyesi değişimi üzerinde durulmuştur.
} 
Antropojenik İklim Değișikliğine Bağlı Deniz Seviyesi Değișiminin Sinop Yarımadası'na Olası Etkileri faaliyetlerin etkisi ile oldukça hızlı şekilde yaşanan bir gerçektir (Ward, 2014; Şüküroğlu, 2014; Erinç, 2015).

Jeomorfoloji üzerinde derin etkiler bırakan deniz seviyesi değişimleri, kuşkusuz beşeri hayat üzerinde de büyük etkilere yol açmıștır. Suların yükselmeye başlamasından önce Dünya'nın kimi taraflarına yayılmıș insan topluluklarının dıș dünyayla olan bağlantıları kopma noktasına geldi, kimileri ise uzun bir süre boyunca tamamen izole bir hayat sürmeye başladı. Örneğin günümüzde birbirinden kopuk olan Yeni Gine ve Avusturalya'da yaşayanlar son transgresyonla birbirinde ayrılmıştır. Bu ayrılık sonucunda Yeni Gine'de yaşayanlar; erzak biriktiren, daha yoğun nüfuslu ve geniş bahçelere sahip bir topluluğa dönüşürken, Avusturya'dakiler avcı-toplayıcı yaşamlarına devam ettiler (Blainey, 2005).

Günümüzde hâlihazırdaki 15 - 20 cm'lik deniz seviyesi artışı, büyük ölçekli küresel bir krize yol açmamış olsa da özellikle Hollanda, Danimarka ve Bangladeş gibi deniz seviyesine yakın veyahut deniz seviyesinden aşağıda toprakları olan ülkeler için küçük artışlar bile önem arz etmektedir. Çünkü deniz seviyesi artışı yalnızca denizin karayı işgal etmesiyle değil, aynı zamanda tarımsal alanların tuzlanması ve bu sebepten dolayı tarımsal verimin düşmesi gibi etkilerle de kendini gösteren bir durumdur (Akın, 2006). Yayınlanan iklim tahmin raporları, deniz seviyesi artışının yaşanmaya devam edeceğini söylemekte ve çeșitli projeksiyonlarla birkaç yüzyıllık tahminler yapmaktadır. Metreleri bulan yükselmeyle suya gömülen kıyı bölgelerden daha güvenli yerlere yaşanması muhtemel göçler özellikle alçak kıyı bölgelerde büyük şehirlere sahip ülkeler başta olmak üzere tüm Dünya'daki sosyoekonomik yapıyı sarsma potansiyeline sahip büyük bir tehdittir (Özey, 2014; Ward, 2014; Boşgelmez, 2007).

Üç tarafı denizlerle çevrili olan Türkiye'nin, küresel deniz seviyesi değişimlerden etkilenmesi kuşkusuz kaçınılmazdır. Türkiye kıyıları yaklaşık 30 milyon insana ve ülkenin GSMH'nin yarısından fazlasına - yaklaşık \%60'ına - ev sahipliği yapmaktadır. Simav, Şeker, Tanık ve Gazioğlu'nun yaptığı (2015); Türkiye kıyılarındaki risk alanlarını belirlemiş çalışmaya göre, Türkiye kıyılarında deniz seviyesi yükseliminden en çok etkilenecek alanların; Adana, Antalya, Çanakkale, Edirne, Mersin ve Samsun'a benzer şekilde; kıyılarında deltalar gibi alçak alanlara sahip iller olacağı saptanmıştır. Yine aynı çalışmaya göre Türkiye'nin orta seviye risk taşıyan ülkeler içinde olduğu sonucuna varılmıştır. Benzer bulguları, Geymen ve Dirican (2016) da CBS kullanarak yaptıkları risk analiziyle tespit etmiş, 2500 yılında Türkiye topraklarının yaklaşık $\% 0,70$ 'nin yükselen sulardan doğrudan etkileneceği sonucuna ulaşmıștır.

Küresel deniz seviyesi için yapılan tahminler, Dünya genelindeki olası sonuçları verse de kimi kıyı alanlarında küresel deniz seviyesi değişim hızından farklı, yerel sonuçlara ulaşmak mümkündür. İçinde bulunduğumuz yüzyılda, deniz seviyesinde bölgesel olarak $\pm 15 \mathrm{~cm}$ farklılıkların görülmesi beklenmektedir. Kıyı bölgelerin düşey yer kabuğu hareketlerine sahip olması durumunda deniz yükselmesinin artış hızı diğer bölgelere göre çok daha hızlı olabilmektedir. Türkiye'yi çevreleyen denizlerin küresel ortalamadan çok daha hızlı bir şekilde $4-6 \mathrm{~mm}$ yükseldiği, deniz seviyesi ölçüm istasyonlarınca tespit edilmiştir (Simav, Şeker, Tanık ve Gazioğlu, 2015; Yıldız, Demir, Gürdal, Akabalı, Demirkol ve Ayhan, 2003). Küresel deniz seviyesinin gelecekteki durumu hakkında çeşitli tahminler olmakla beraber8, çalışmada IPCC'nin 2013'de yayınladığı 5. değerlendirme raporu temel alınacaktır (tablo 1). Ayrıca değerlendirme aşmasında, Geymen ve Dirican'nın (2016) CBS kullanarak yaptıkları çalışmaya benzer şekilde IPCC'nin 5. değerlendirme raporundaki yüksek olasılıklı senaryodan en büyük değerler kullanarak harita üretimi ve etki değerlendirmesi yapilacaktır.

\footnotetext{
${ }^{8}$ Eski NASA araştırmacısı James Hansen; önümüzdeki yüzyılda deniz suyu seviyesi artışının - IPCC raporlarında belirtilenden daha yüksek bir şekilde - birkaç metre olacağını tahmin etmektedir (URL 5).
} 
Tablo 1: IPCC 5. değerlendirme raporuna göre deniz seviyesinde beklenen değişimler

\begin{tabular}{|l|cccccc|}
\hline \multicolumn{2}{|c|}{ Senaryo* } & 2100 & 2200 & 2300 & 2400 \\
\hline Su artışına katkıda & Düşük & 0.26 ila $0.53 \mathrm{~m}$ & 0.35 ila $0.72 \mathrm{~m}$ & 0.41 ila $0.85 \mathrm{~m}$ & 0.46 ila $0.94 \mathrm{~m}$ & 0.50 ila $1.02 \mathrm{~m}$ \\
bulunan ögeler & Orta & 0.19 ila $0.66 \mathrm{~m}$ & 0.26 ila $1.09 \mathrm{~m}$ & 0.27 ila $1.51 \mathrm{~m}$ & 0.21 ila $1.90 \mathrm{~m}$ & 0.18 ila $2.32 \mathrm{~m}$ \\
toplamı** & Yüksek & 0.21 ila $0.83 \mathrm{~m}$ & 0.58 ila $2.03 \mathrm{~m}$ & 0.92 ila $3.59 \mathrm{~m}$ & 1.20 ila $5.17 \mathrm{~m}$ \\
\hline * Senaryolar, belirsiz gelecekte neler olabileceğini birtakım özel kabuller altında araştırmada kullanılan yoldur (Lutgens, Tarbuck ve Tasa, 2014). \\
** Tablo IPCC'nin 2013'de yayınladığı 5. değerlendirme rapordan değiştirilerek alınmıştır (Kaynak: http://www.climatechange2013.org).
\end{tabular}

\section{ARAŞTIRMA SAHASININ COĞRAFİ KONUMU VE BAŞLICA ÖZELLÍKLERİ}

Kuzey Anadolu Dağları kavisine paralel bir şekilde hat çizen Karadeniz kıyılarının oldukça düzgün olan uzanışı, bazı önemli burunların meydana getirdiği çıkıntılarla bozulur, bu çıkıntıların en önemlilerinden bir tanesi de Sinop Yarımadası'dır (Şekil 1). Sinop Yarımadası, Gerze - Erfelek ile Ayancık'ın doğusundaki Oluza çayının ağzı arasında kabaca çizilen bir hattın kuzeyidir (Akkan, 1975). Sinop Yarımada'sı üzerinde Türkiye'nin en tipik berzah şehri olan Sinop'un nüvesinin kurulu olduğu Sinop tombolosu (Boztepe Yarımadası), Sinop Yarımadası üzerindeki daha küçük başka bir yarımadadır (Ceylan, 2011). Bu tombolo 1,5 km uzunluğunda olup en dar yeri yaklaşık 300 m'dir. Yarımadanın üzerinde yer alan bir diğer önemli kıyı oluşum şekli de Anadolu'nun en kuzey ucu olan İnceburun'dur. İnceburun'un da içerisinde bulunduğu yarımadanın kuzey kesimlerinden güney istikametine doğru gidildikçe yükseklik artar. Yarımadanın güney kesimi boyunca uzanan Küre (İsfandiyar) Dağları'nın kuzeye bakan kesimleri, drenajı sağlayan akarsuların faaliyetleri sonucu oluşmuş derin ve dar vadilerin sıkça bulunduğu bir görünüm kazanmıştır (Gürbüz, 2000). Öyle ki sahile yakın kesimlerde yükseklik 200 m'yi geçmemesine rağmen engebeli bir görünüm hâkimdir. Yarımada üzerindeki bu görünümü sağlamış akarsuların en önemlisi, denize döküldüğü yerde küçük bir delta oluşturmuş, bölgenin en büyük akarsuyu olan Karasu Çayı'dır. Karasu Çayı kaynağını aldığı Küre Dağları'ndan kuzey istikameti boyunca akar ancak araştırma sahamıza girdikten sonra aniden yön değiştirip ilk önce doğu, ardından kuzeydoğu istikameti boyunca, tarımın geliştiği geniş bir alüvyal ovada akmaya devam ederek 80 km'nin sonunda Karadeniz'e ulaşır. Disimetrik bir vadi içerisinde yer alan akarsu; doğu istikameti boyunca aktığı bölümde güneyden gelen kollarlarla beslenir, kuzeyden yalnızca yağışlara bağlı oluşmuş uzunlukları kısa olan sel yarıntıları ile beslendiğinden bu kesimde Karasu su toplama havzasının kuzey sınırı akarsuya oldukça yaklaşır. Karasu haricinde pek çok kısa akarsu yarımadanın muhtelif yerlerine dağılmış olup, yer yer farklılıklar barındırmakla beraber, dandritik bir akarsu ağı yaygındır (Akkan, 1975). Sinop Yarımadası'nın kuzeybatısında tektonik hareketler sonucu oluşmuş bir çukur alan üzerinde konumlanan ve esasen bir lagün olan Sarıkum, yarımadanın en büyük gölüdür. Deniz seviyesinden 4-5 metre yüksekteki gölü besleyen iki kaynak olan Dereönü ve Keçi deresi yazın kurumaktadır. Bu duruma sentripetal olan akarsu drenajının oldukça dar bir alana yayılması ve göl çevresindeki gevşek kumulların yağış sularını tabana sızdırması neden olmaktadır (Yılmaz, 2005). "Sarıkum Tabiat Koruma Alanı içinde barındırdığı bitki ve hayvan türleri ve bunların yaşama ortamlarındaki çeşitlilik, kuşların göç yolları üzerinde bulunması, çok kalabalık kuş gruplarına beslenme ve konaklama sağlaması ile Ramsar Kriterlerine göre Uluslararası sulak alan ekosistemi özelliği taşımakta olup Türkiye bu statüdeki 135 sulak alandan birisidir (URL 6)". Araștırma sahamızdaki bir başka önemli hidrografik alan ise uzunluğu 2.5-3 km, genişliği ise $1 \mathrm{~km}$ civarında olan, yılın büyük bir kısmı sazlıklarla kaplı Aksaz bataklıklarıdır. Yağış̧ı dönemlerde bir gölcük görünümü kazanan Aksaz bataklık alanı, Sarıkum'a benzer şekilde oluşmuş ancak çok daha süratle karalaşmış bir alana karşılık gelmektedir (Akkan, 1975). 


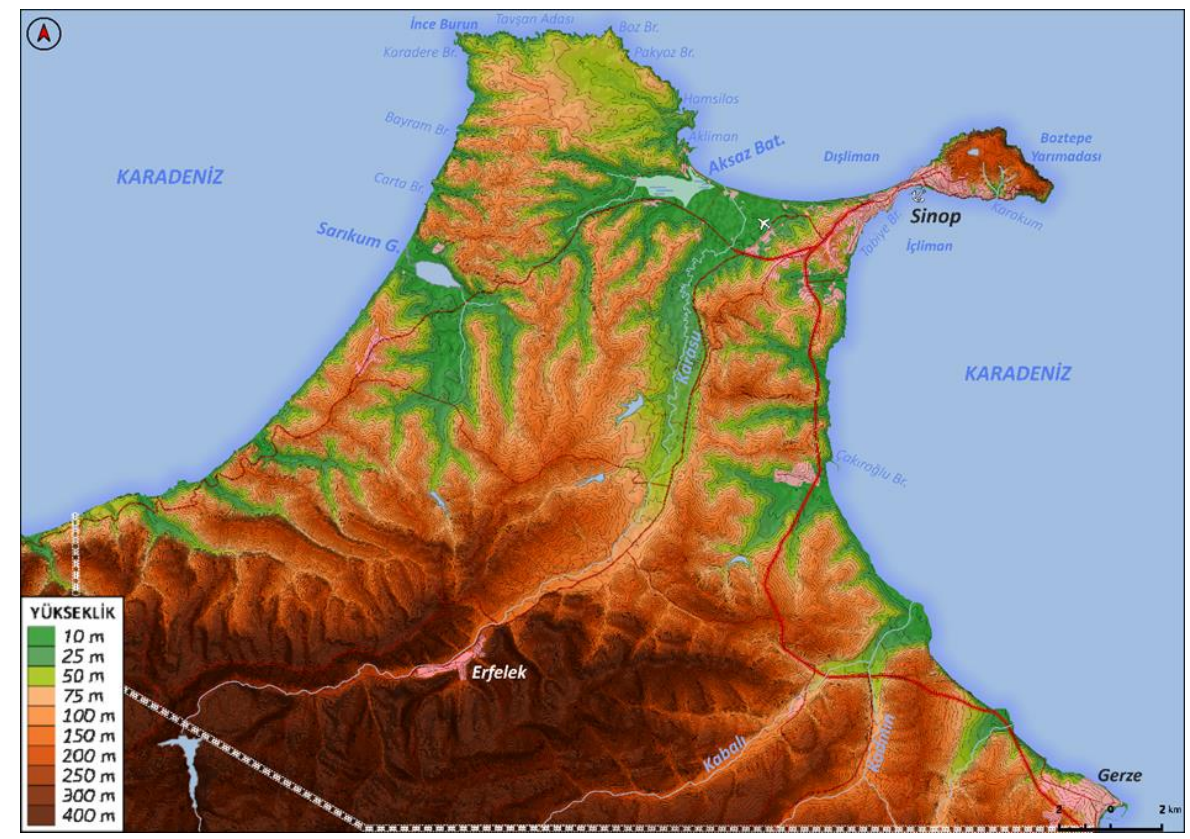

Şekil 1. Sinop Yarımadası Fiziki Haritası. (Harita; Akkan, E. Sinop Yarımadasının Jeomorfolojisi (1974)'den değiştirilerek, srtm.csi.cgiar.org9 adresinden alınan, Dijital Yükseklik Verileriyle oluşturulmuştur)

Yarımada genelinde hâkim olan iklim Köppen - Geiger iklim sınıflandırmasına göre Cfa olarak kodlanmış olan, yazları sıcak ve her mevsim yağışlı, ılıman - nemli bir yapıdadır. Bu iklim tipi Karadeniz kıyıları boyunca yaygın olan bulutluluğun fazla, buharlaşmanın az olduğu bir iklim tipi olup yüksekliğe bağlı olarak yarımadanın güneyine doğru ilerledikçe sıcaklık değerleri düşmektedir. Sinop ili ortalama sıcaklığı yıllık bazda $14.1^{\circ} \mathrm{C}$, aylık toplam yağış miktarı ortalaması ise 686.3 mm'dir (Öztürk, Çetinkaya ve Aydın, 2017; URL 7; URL 8). Ancak küresel iklim değişikliği kendini yarımada üzerinde de göstermektedir, bölgede sıcaklığın arttığı buna bağlı olarak yağışların etkilendiği ve tarımsal verimin düştüğü görülmüştür. Ayrıca etkisi kentsel alanlar üzerinde gittikçe artan kısa süreli sağanakların şiddeti de artmaktadır (Ülke ve Özkoca, 2018).

Sinop Yarımadası'ndaki en önemli yerleșim alanları genel olarak kıyı șeridinde toplanmıştır, bu merkezlerden en önde geleni doğal limana sahip olmasından dolayı tarih boyunca stratejik bir öneme sahip olmuş ancak limanın hinterlandının dar olmasından dolayı gelişimi olumsuz etkilenmiş Sinop şehir merkezidir. Sinop, yaklaşık 42 bin kişilik nüfusuyla araştırma sahamızın en büyük yerleşim yeridir. Kıyıda kurulu bir kasaba olan Gerze ise yaklaşı 16 bin kişilik nüfusuyla yarımadanın en büyük ikinci yerleşim yeridir. Erfelek ise Karasu Çayı'nın kenarında kurulmuş büyük bir köy niteliğini taşıyan yaklaşık 3500 kişilik nüfusa sahip bir ilçe merkezidir. Yarımada boyunca dağınık bir dağılışa sahip irili - ufaklı köyler dışında önemli bir yerleşim alanı bulunmamaktadır. Merkez, Gerze ve Erfelek ilçelerinin toplam nüfusları ise yaklaşık 100 bin kişidir (Kaya ve Yılmaz, 2017; TUIK, 2018).

Yarımada üzerinde Sinop’a 8 km uzaklıkta bulunan ve yıllık 150.000 kişi kapasiteli Sinop Havalimanı, şehir ulaşımı açısından oldukça önemli bir tesistir. Şehir merkezini doğrudan Samsun'a bağlayan D.010-14 kodlu bölünmüş yol yarımadayı dışarıya bağlayan en önemli karayoludur. Bu bölünmüş yola ek olarak Boyabat ve Ayancık ilçe merkezlerini yarımadayla birleştiren karayolları da ulaşım açısından oldukça önemlidir. Yarımada üzerinde demiryolu yer

\footnotetext{
${ }^{9}$ Reuter H.I, Nelson A. \& Jarvis, A. (2007). An evaluation of void filling interpolation methods for SRTM data, International Journal of Geographic Information Science, 21:9, 983-1008.
} 
Afet ve Risk Dergisi Cilt: 2 Sayı: 2, 2019 (64-79)

Yusuf Mert ÜSTÜN

almamakta, fiziki şartlar açısından elverişli olmasına karşın gelişkin bir liman da bulunmamaktadır. Yalnızca Sinop şehir merkezinde küçük sayılabilecek, ancak yarımadanın en büyüğ̈ olan, ve konteyner rıhtımı bulunmayan bir liman bulunmaktadır (URL 9; URL 10)

\section{AMAÇ}

Son yıllarda ivmelenerek artan ve İnsan kaynaklı sera gazı etkisinin büyük ölçüde etkilediği küresel iklim değişikliği, kuşkusuz günümüzün - ve verilerden yola çıkan tahminler ışığında da geleceğin - en önemli problemlerinden biridir. İnsan medeniyetinin atmosfere boca ettiği sera gazları, Dünya'nın sıcaklığını hissedilir ölçüde arttırmakta ve probleme yol açmaktadır (Gautier, 2014). Sera gazlarının yapısını bozduğu atmosferimiz ve dolayısıyla Dünya'mız hızla ısınmakta; böylece iklimlerin yayılış alanları değişmekte, kurak bölgeler genişlemekte, ekstrem hava olayları daha sık görülmekte ve buzullar erimektedir. Küresel iklim değişikliğine bağlı olarak eriyen buzullar dünya çapında deniz seviyesini değiştirmektedir. Deniz seviyesinde yaşanan değişikler ise kıyı bölgelerindeki doğal hayatı ve beșeri faaliyetleri derinden tehdit etmektedir (Özey, 2014). Araștırmada; Coğrafi Bilgi Sistemleri kullanılarak küresel iklim değișikliğine bağlı deniz seviyesi değişiminin Sinop Yarımadası üzerinde olası etkilerini ortaya koymak amaçlanmaktadır.

\section{YÖNTEM}

Küresel deniz yükselmesi için temel alınan tahminler, Dijital Yükseklik Verisi, "SRTM" sisteminden alınan raster formatındaki yükseklik verilerinin, QGIS.3.2 yazılımı kullanarak oluşturan haritalar ile incelenmiştir (Şekil 1, 2, 3, 4 ve 5). Belirtildiği üzere, değerlendirmemizde IPCC 5. değerlendirme raporuna göre deniz seviyesinde beklenen değişimlerin; 2100, 2200, 2300, 2400 ve 2500 yılları için yüksek ihtimalli tahminlerin içindeki büyük sayılar kullanılmıştır (Tablo 2). Haritalama sürecinde, tektonik hareketlerin etkileri ile bölgesel olarak farklılık gösterebilecek deniz seviyesi yükselme hızı dâhil edilmemiş, yarımada üzerinde deniz seviyesindeki artıştan etkilenen yerler birbirinden kopuk dar alanlar olduklarından en çok etkilenen bölgeler ayrı - ayrı haritalandırılarak incelenmiş; beşeri sistemler olan nüfus, karayolları ve diğer altyapıların günümüzdeki durumu esas alınmıştır.

Tablo 2. Haritalandırmada esas alınan deniz yükselmesi

\begin{tabular}{|c|ccccc|}
\hline Y1llar & 2100 & 2200 & 2300 & 2400 & 2500 \\
Yükseklik & $0.83 \mathrm{~m}$ & $2.03 \mathrm{~m}$ & $3.59 \mathrm{~m}$ & $5.17 \mathrm{~m}$ & $6.63 \mathrm{~m}$ \\
\hline
\end{tabular}

\section{KÜRESEL DENIZ SEVIYESI DEĞIŞ̧IMI'NİN SINOP YARIMADASI ÜZERINNDEKI OLASI ETKILERI}

Deniz seviyesi nadir bir şekilde farklılaşmadan uzun süre boyunca kalır, bu yüzden kıyılar her an değișebilen dinamik bir yapıya sahiptir. Bu durum pek çok kıyı şeklinin nispeten hassas ve kısa ömürlü olmasıyla kendini gösterir (Lutgens, Tarbuck ve Tasa, 2014; Huggett, 2015). Stabil olmayan koşullardan dolayı kıyıların gelecekteki durumunu tahmin etmesi de zorlu bir iş haline gelmektedir. Bu yüzdendir ki kıyı şeridinin konumu ve bu konumun değişikliğine bağlı etkiler hakkındaki uzun vadeli tahminlerde tam doğrulukta bir sonuç bulmak oldukça zorlu bir iştir. Ayrıca bu durumlara ek olarak kara ile etkileşime geçen kısımlardaki kayaç yapısı, dalgaların hızı gibi faktörler de olaya dâhil edilince tahminde bulunmanın zorluğu daha da artmaktadır. Bu sebeplerden kaynaklı olarak değerlendirme sürecinde kıyılar üzerindeki "olası" etkilere ulaşılmaya çalışılmıştır. 
Antropojenik İklim Değișikliğine Bağlı Deniz Seviyesi Değișiminin Sinop Yarımadası'na Olası Etkileri Buzulların erimesi ve deniz suyunun termal genleşmesinin deniz seviyesini yükseltmesi, kıyılar üzerinde büyük değişimlere yol açacaktır. Dünya kıyılarının boğulması durumunda, yeni kıyı şekilleri oluşacak ve stabilleşmiş kimi kıyılar tekrar denizel etkinin altında kalacaktır. Böylece kimi olgunlaşmış ve son 6000 yılda egemen olan deniz seviyesi tarafından oluşturulmuş falezler tekrar dalgaların etkisine maruz kalacak, kıyı erozyonu yaygınlaşacak ve hızlanacaktır. Kumsallar ise yeteri kadar dolgu malzemesi birikmesine uygun olmayan - örneğin, akarsu ağızları gibi - kimi alanlar dışında giderek küçülecek ve varlık mücadelesi verecektir. Son on yılda yıllık 1-2 mm'lik deniz seviyesi yükselmesi dahi birçok yerde kumsal erozyonuna neden olmuştur. Kıyılardaki kayaçların yapısı kıyı çizgisinin konumunun değişimi üzerinde oldukça önem arz etmektedir, Güneybatı İngiltere'de bulunan tebeşirden oluşmuş falezler, dalgalar tarafından oldukça yüksek bir hızla geriletilmiştir (Huggett, 2015). Baston yakınlarında bulunan; kötü tutturulmuş buzul çökellerine sahip Cod Burnu'nun, yllda 1 metre kadar karaya doğru geriletecek derecede erozyona uğraması da bu açıdan örnek verilebilir (Lutgens, Tarbuck ve Tasa, 2014). Ancak kıyıların değişimi üzerindeki en etkili faktörlerden biri de rölyeftir. Dağlık ve ani yükselmeyle karşılaşılan yüksek kıyılarda kıyı çizgisinin hareket hızı, alçak ve düz satha sahip kıyalara kıyasla çok daha yavaştır.

Sinop Yarımadası kıyıları ve kıyı alanlarına yakın bölgeleri; denizden karaya doğru ilerlendiğinde arazide karşılaşan ani yükselmenin etkisiyle birlikte, denizin kara içine doğru genişlemesinden büyük ölçüde korunacağı tespit edilmiştir. Bu açıdan Sinop Yarımadası'nın; ABD’nin Meksika Körfezi'ne komşu olan Güney eyaletlerinin veya Hollanda ile Belçika'nın alçak kıyı kesimleriyle karşılaştırıldığında oldukça güvende kalacak bir bölge olduğu söylenebilir. Nitekim gelecekteki deniz seviyesi yükselmesine bağlı olarak oluşabilecek potansiyel risklerin anlaşılmasına yardımcı olan, Kıyı Etkilenebilirlik Endeksine (CVI) göre Sinop vilayeti "orta" seviyede etkilenebilirlik değerine sahiptir (Simav vd., 2015).

Sinop yarımadası, üzerindeki akarsuların denize kavuştukları kısımlar başta olmak üzere kıyılardaki dar kesimler deniz seviyesi yükselmesi sırasında etkilenebilecek alanlar olacaktır (Şekil 2). Etkilenecek alanların başında yarımadanın kuzeyinde bulunan depresyonlar olan Sarıkum Gölü çevresi, Aksaz Bataklıkları ve Karasu Çayı'nın Karadeniz'le birleștiği kısımlar yer almaktadır. Bu iki bölge ve yarımadanın en önemli yerleşimi olduğundan, Sinop şehir merkezi tek tek değerlendirilmiştir.

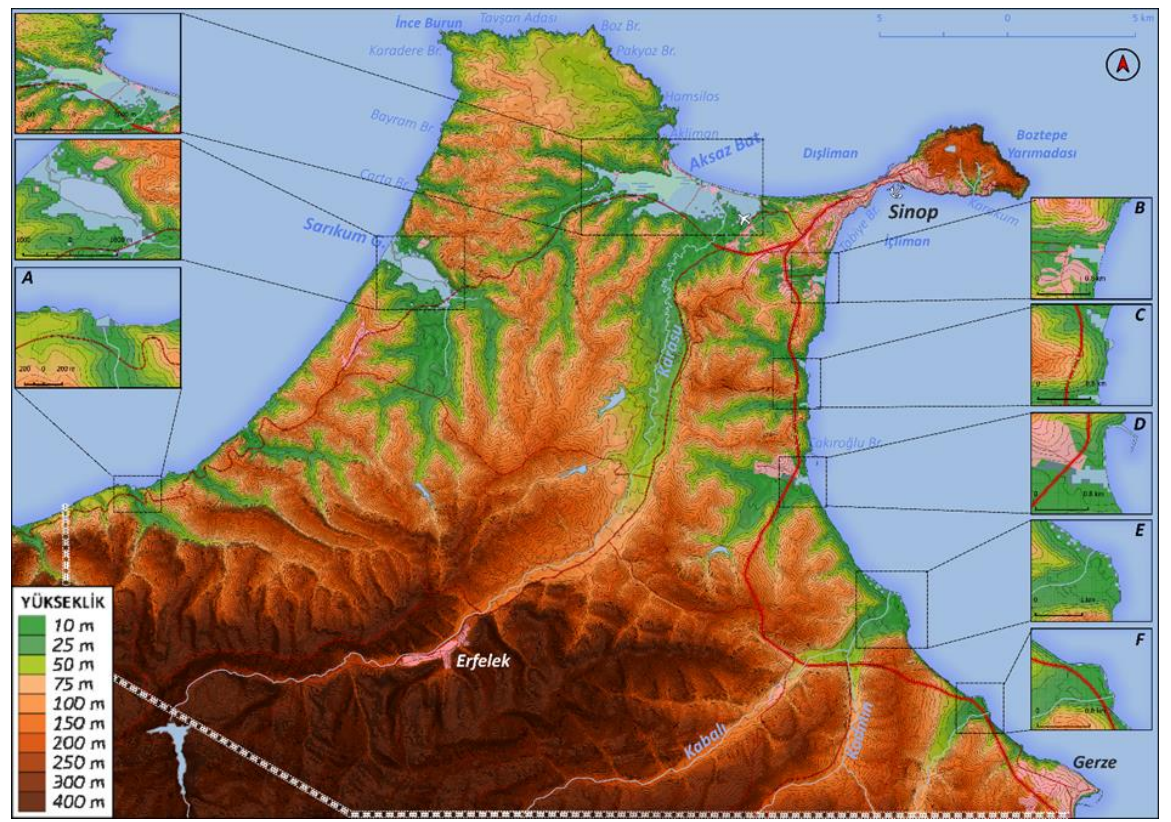

Şekil 2. Sinop Yarımadası'nda 2500 Yılında En Çok Etkilenmesi Beklenen Bölgeler 


\subsection{Araştırma Sahasında Küçük Akarsuların Denize Döküldükleri Havzalardaki Olası Etkileri}

Tarakçı Deresi ve Gebelit Çayı'nın birleşerek, denize döküldügü yerde küçük balıkçı teknelerine sığınma imkânı sağlayan, "Gebelit Koyu" olarak bilinen alan (Şekil 2-a); Sinop şehir merkezinin güneybatısındaki Korucuk köyü sınırları içerisindeki Korucuk Deresi'nin denizle birleștiği yer (Şekil 2-b); Sinop şehir merkezinin güneybatısındaki Çiftlik ve Ordu köylerinin sınırları içerisindeki Haznedar Deresi'nin denizle birleștiği kısım (Şekil 2-c); Çakıroğlu Burnu'nun hemen güneyindeki, Sinop OSB'nin de yakınında bulunduğu Mollaoğlu, Yenicuma, Çorak ve Aşılık derelerinin birleșerek denize döküldüğü bölüm (Şekil 2-d) ${ }^{10}$; Kabalı ve Kadının çaylarının birleşerek denize döküldüğü alçak bölge (Şekil 2-e) ile Sarımsak Çayı'nın Gerze şehir merkezinin kuzeybatısında denize döküldügü alan (Şekil 2-f), alçak alanların küçük çaplı su baskınlarına maruz kalacağı tespit edilmiștir. Ayrıca yarımada boyunca aralıklarla uzanan kumsalların büyük ölçüde yok olacağı sonucu çıkartılmıştır.

\subsection{Karasu Cayı Havzası ve Aksaz Bataklıkları Cevresindeki Olası Etkileri}

Yarımada üzerinde deniz seviyesi yükselmesinden en çok etkilenmesi beklenen alan; Akliman ile Sinop Havalimanı arasında kalan, Karasu Çayı'nın Karadeniz'e döküldüğg̈ alandır (Şekil 3). Bu nispeten düz olan bölge, Aksaz bataklıkları ile Karadeniz'in müşterek olarak, büyük ölçüde doğu ve güney istikameti olmak üzere genişleyeceği bir ovadır. Bu genişleme sırasında Aksaz bataklıklarının Karadeniz'e yakın ve alçak kesimleri deniz sularının basmasıyla yok olma ve diğer alanlarda genişleme eğilimindedir. Karadeniz ve yağışlarla birlikte gölcük görünümü kazanan, Aksaz'ın olası genişlemesinin; bölgedeki tarım alanlarını su basması veyahut toprakta tuzlanma ile yeraltı sularına tuzlu deniz sularının karşıma tehlikesini doğurduğu anlaşılmıştır. Ayrıca deniz seviyesi yükselmesi sırasında yok olacak kumsallar ve bu kumsalların yakınlarındaki turizm işletmelerinin olumsuz yönde etkilenmesi, yükselmenin Sinop ile Akliman arasındaki turizm faaliyetlerini yok etme tehlikesi taşıdığı saptanmıştır. Sinop için iki önemli ulaşım aksı olan, Sinop - Ayancık arasında ulaşımı sağlayan D010-14 karayolu ve Sinop Havalimanı'nın tamamen olmasa da bir kısmının, Akliman Koyu ile Sinop arasında ulaşımı sağlayan kıyıdaki karayolunun da tamamının, doğrudan su basması ya da su basma tehlikesi altında kalacağı tespit edilmiștir. Su altında kalacağı tahmin edilen alanda yoğun bir nüfuslanma olmamakla beraber sahil hattında Bostancılı köyüne bağlı kimi yerleşimler bulunmaktadır, söz konusu bölge yaz aylarında kıyıdaki turizm alanlarının etkisiyle daha kalabalık bir hale gelmektedir. Bostancılı köyü Tuik'e göre 2017 yılı itibariyle 1073 kişilik bir nüfusa sahip olup bu nüfusun önemli bir kısmı deniz seviyesi yükselmesinden etkilenmesi muhtemel alanın dışında kalmaktadır.

\subsection{Sarıkum Gölü ve Cevresindeki Olası Etkileri}

Yarımada üzerinde deniz seviyesi yükselmesinden en çok etkilenmesi beklenen başka bir alan da Sarıkum Gölü ve çevresidir (Şekil 5). Daha önce bahsedildiği üzere göl ve çevresi; tektonik hareketler sonucu çöken bir bölgenin körfeze dönüştükten sonra, kendini besleyen dereler ve karayelin etkisiyle biriken doğal dolgu malzemelerinin ortaya çıkarttığı set sonucu oluşmuştur. Göl hali hazırda; tuz ve sodyum oranının çok yüksek, organik madde ve potasyum oranlarının yüksek, killi ve orta derecede kireçli, berrak, kokusuz ve içilemez nitelikte olan bir su kütlesine sahiptir. Deniz seviyesinin 6 metreyi aşacak bir şekilde yükselmesiyle birlikte deniz seviyesinden 4-5 metre yükseklikteki gölün deniz sularıyla dolması ve çevresindeki bataklık alanların genişlemesi beklenmektedir. Bu hareketler sonucu tabiat koruma alanı ilan edilmiş göl ve çevresinin, doğusundaki tarım alanlarının olumsuz etkileneceği, hassas ekosisteminin bozulacağı ve göl olmaktan çıkıp küçük bir körfeze dönüşeceği saptanmıştır. Bu dar ve nispeten küçük sayılabilecek alanda birbirinden farklı - kıyı kumulları, göl, ormanlar, yalancı maki toplulukları,

\footnotetext{
10 “Samsun Ulaştırma 9. Bölge Müdürlüğ̈̈’nün yaptı̆̆g çalışmalar doğrultusunda kıyı erozyonu ve tahribatına önlemek amacıyla Sinop İli Yalıköy Mevkii'nde kıyı koruma yapısı yapıları yapılması kararı alınmıştır (URL 11).”
} 
Antropojenik İklim Değișikliğine Bağlı Deniz Seviyesi Değișiminin Sinop Yarımadası'na Olası Etkileri deniz kıyısı kayalıkları, sulak çayırlar, ağaçlandırma sahaları gibi - ekosistemler bulunmaktadır. Ayrıca küresel ölçekte tehdit altında iki tür olan "Verbascum degenii”, "İsatis arenaria” ve Avrupa ölçeğinde tehdit altında iki tür olan "yclamen coum”, "Crocus spedosus'un” yaşam alanıdır. Su basması tehlikesi altındaki alan kalabalık bir nüfusa sahip değildir, yalnızca gölün kuzeydoğusunda yoğunlaşan ve 2017 yılı itibariyle nüfusu 149 kişi olan Sarıkum köyü başlıca yerleşimdir (Tuik, 2018; URL 6; Yılmaz, 2005).

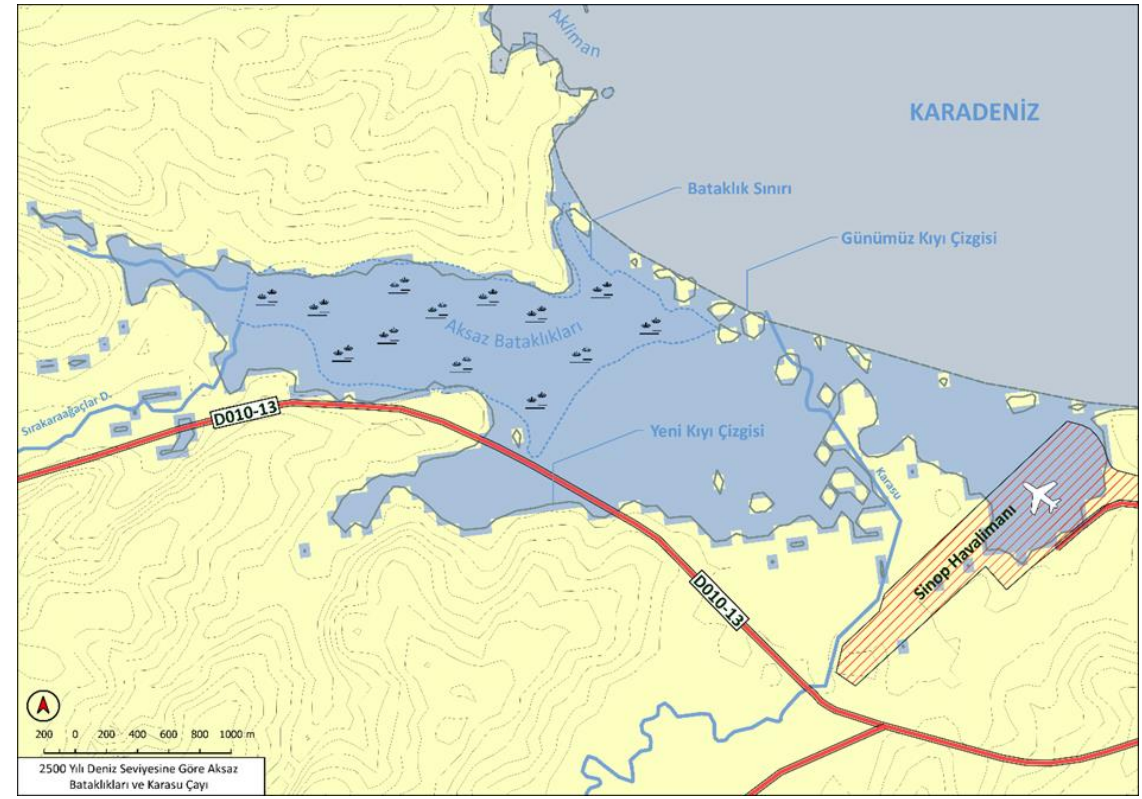

Şekil 3. 2500 Yılı Karasu Çayı Ağzı ve Aksaz Bataklıkları Çevresi Tahmini Deniz Seviyesi

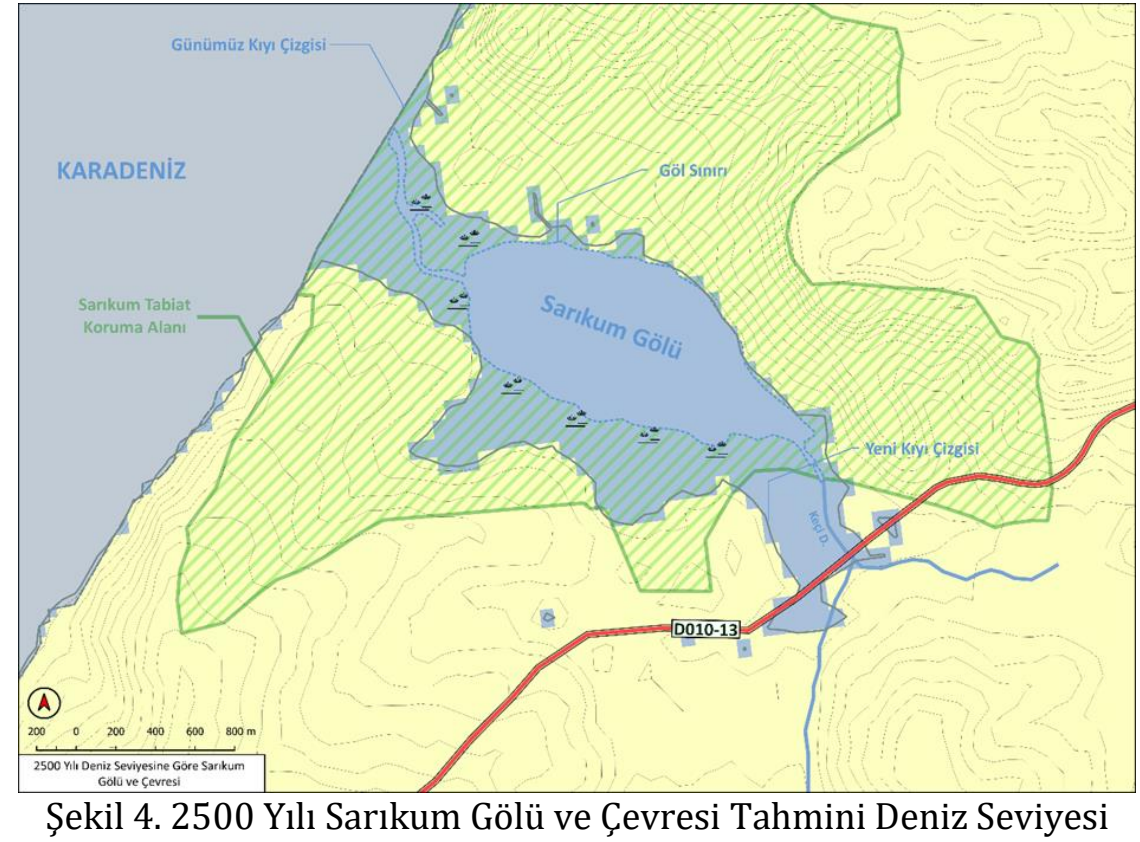

\subsection{Sinop Şehrine Olası Etkileri}

Yükselmiş bir tombolonun berzahı üzerinde kurulmuş Sinop şehir merkezi 2500 yılın için tahmin edilen 6.13 metrelik deniz seviyesi yükselmesinden yüksek kıyılarının sağladığı avantaj dolayısıyla büyük ölçüde korunacaktır. Ancak şehrin kuzey kıyılarındaki kumsallar sular altında 
Afet ve Risk Dergisi Cilt: 2 Sayı: 2, 2019 (64-79)

Yusuf Mert ÜSTÜN

kalacaktır, tarihi değer taşıyan Sinop Kalesi - eğer ileride önlem alınmazsa - kendisini korumak için iki aşamada yapılmış mendirekler ${ }^{11}$ sular altında kalacağından, Karadeniz'in dalgalarına karşı korunmasız bir hale gelecektir. Bu tarihi alan ve kumsallar dışında falezli kuzey kıyısında tahribata neden olacak bir etki olması beklenmemektedir. Şehrin kuzey kıyılarına kıyasla daha alçak olan güney kıyılarında deniz seviyesinin yükselmesi daha büyük bir etkide bulunacaktır. Sinop Limanı, tersane, Barış Manço Parkı, kıyı boyunca uzanan caddelerin bir kısmı - özellikle Gazi, Bülent Ecevit ve Enver Bahadır Caddesi'nin alçak kesimleri - ile yer yer kesintiye uğrayarak kıyı boyu uzanan kumsallar 2500 yılına kadar sular altında kalacaktır. Kuzey sahilinden farklı olarak burada alçak meskenler ve Rıza Nur Kütüphanesi gibi kimi tarihi yapılar sulara gömülecek, kuzey sahiline benzer bir şekilde Karadeniz'e tekrar kavuşan burçlar, dalgalar tarafından tehdit edilecektir. Her ne kadar dar alanlar su seviyesi değişiminden etkilense de şehrin; turizm, ticaret ve sosyokültürel olarak önemli kimi merkezlerinin tahribatı şehri olumsuz yönde etkileyecektir.

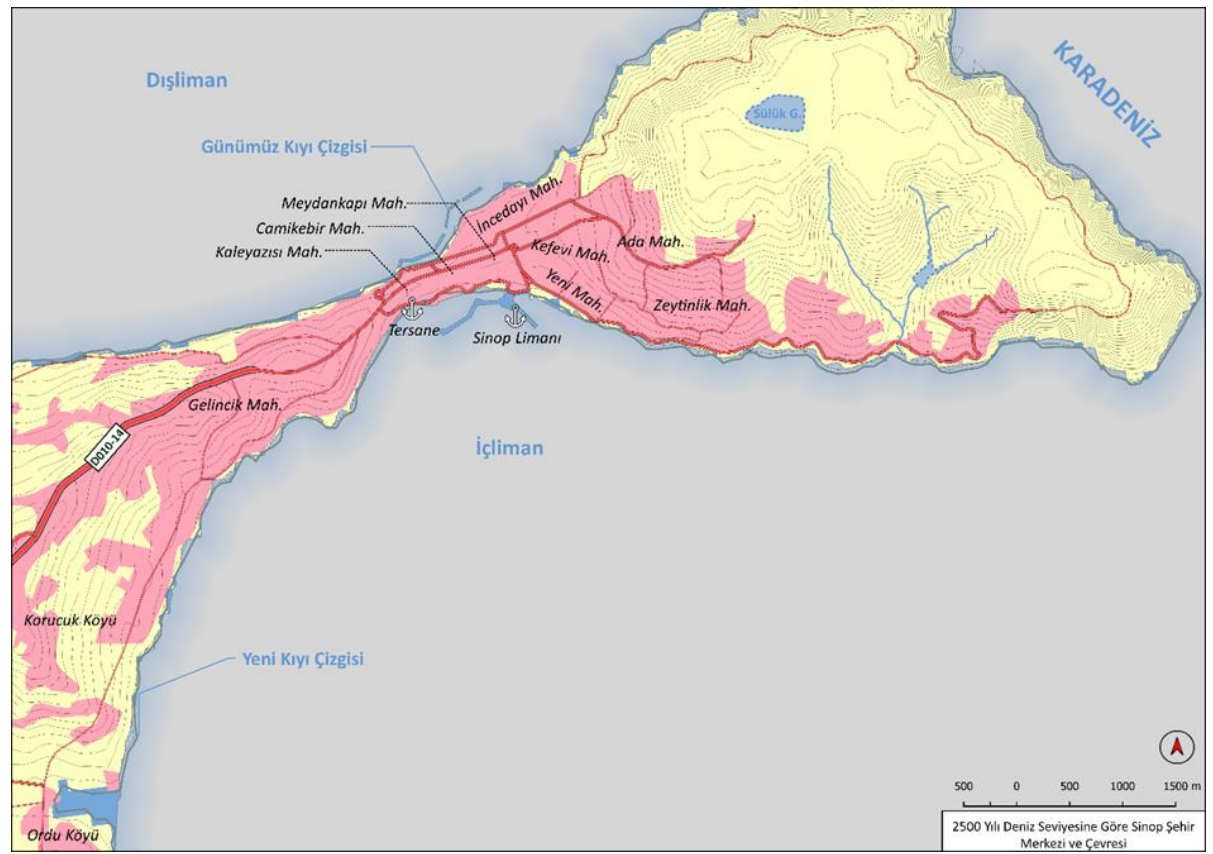

Şekil 5. 2500 Yılı Sinop Şehri ve Çevresi Tahmini Deniz Seviyesi

Sinop yarımadası ve Dünya kıyılarında da görülecek bu olası etkilerden kaçınmak ve kıyıyı korumak maksadıyla önlem alınmak istenecektir, ancak deniz seviyesi yükselmesine bağlı alınacak önlemler kuşkusuz uzun vadede yetersiz olacaktır. Günümüzde kıyııı dizginlemek için alınan önlemlerin gelecekte ne kadar ișe yarayabileceği kuşkuludur, zira sert stabilizasyon yapıları olan kıyı dalgakıranları, mahmuzlar, açık deniz dalgakıranları ve kıyı duvarları ile setlerin tüm bir kıyıyı koruması için oluşacak yapım maliyetleri oldukça yüksektir. Ayrıca kıyı çizgisinin sürekli olarak yükselmeye devam etmesi durumunda alınan önlemlere her geçen gün yenilerini eklemek ve bu istihkâmları sürekli bakım altında tutmak ayrı zorluk ve maliyetleri beraberinde getirecektir. Öte yandan inșa edilmesi muhtemel setlerin firtına ve depremler gibi doğal afetler sırasında yıkılmasıyla birlikte kurulacak setlerin arkasında yaşayanların büyük tehdit altında kalacağı unutulmamalıdır. Yüzyıllardır kıyılarda mücadele veren Hollanda'da geçmişten beri yaşanan bazı vakalar bu amaçla kurulan setler zarar gördüğünde ortaya çıkan afetlere örnek teşkil etmektedir. Zuiderzee Su Baskını olarak bilinen, esasen 1287 ve 1421 yıllarında yaşanan, sırasıyla 50.000 ve 10.000 kişinin hayatını kaybetmesine neden olan bent duvarlarının yıkılmasından

\footnotetext{
${ }^{11}$ Bahsi geçen mendirekler şehrin kalelerini korumak maksadıyla 2011 ve 2016 yıllarında iki aşamada Ulaştırma Bakanlığı tarafından inşa edilmiștir (URL 12; URL 13).
} 
Antropojenik İklim Değișikliğine Bağlı Deniz Seviyesi Değișiminin Sinop Yarımadası'na Olası Etkileri kaynaklı afetler, geçmişte yaşanmış taşkınlara örnek gösterilebilir. 1953 Kuzey Denizi Su Baskını ise hasarlı savunma sisteminin de etkisiyle büyük bir alanın sular altında kalmasıyla sonuçlanan, daha yakın bir dönemde gerçekleşmiş olan, diğer bir su baskınıdır (URL 14; Lutgens, Tarbuck ve Tasa, 2014). Hollanda'daki baskınlara benzer bir şekilde ABD’deki New Orleans şehrinin, Katrina kasırgasının yıktığı koruma duvarlarının himayesinden mahrum kalmasıyla yaşanan su baskının olumsuz etkileri hala devam etmektedir. Sert stabilizasyona alternatif olan kıyıdaki kumsalların beslenmesi yöntemi ise kalıcı çözüm sağlamaktan uzak bir faaliyettir. Kıyıların başka bölgelerden getirilen materyallerle beslenmesine dayalı bu yöntem geniş ölçekteki bir alanda uygulandığında yine büyük masraflar ortaya çıkarmaktadır. Yüksek maliyetlerden ve sürekli tehdit altında kalmaktan uzaklaşmak isteyenlerin kıyı bölgelerini terk etmek suretiyle güvenli kısımlara göç etmesinin oluşturacağı sosyo-ekonomik problemler ise yeni ve daha başka, bir dizi probleme yol açması muhtemeldir.

\section{SONUC VE ÖNERİLER}

Başta beşeri faaliyetlerden kaynaklı sera gazı salınımının tetiklediği sera etkisi, küresel çapta bir iklim değişikliğine neden olmaktadır. Küresel iklim değişikliğine bağlı sıcaklık artışları buzullar üzerinde erimeye neden olmakta ve deniz seviyesini hızlı bir şekilde yükseltmektedir, bu durum kuşkusuz ki Dünya haritalarımızı geçersiz kılacak, beşeri ve doğal hayatı derinden etkileyecektir. Öyle ki küresel çapta 1 metreyi bulacak deniz seviyesi artışından yaklaşık 100 milyon kişinin etkileneceği tahmin edilmektedir. Genel hatlarıyla yüksek kıyılara sahip Sinop Yarımadası, bu deniz seviyesi yükseliminin neden olacağı su basmalarına karşı nispeten korunaklı bir alan olmasına karşın kıyı bölgesindeki hassas ekosistemler başta olmak üzere, turizm ve tarım faaliyetlerinden kaynaklı olarak ekonomik, tarihsel yapıların etkilenmesinden kaynaklı olarak da sosyal yapıda çeşitli tahribatlar olması beklenmektedir. Her ne kadar uzun dönemli bir problem olsa da günümüzde bile etkilerini yağış değişiklikleri vasıtasıyla derinden hissetmeye başladığımız küresel iklim değișikliğine karşı, hızlı bir șekilde etkili önlemler alınması gerekmektedir. Bu önlemler kıyıyı dizginlemeye çalışmak gibi masraflı ve tehlikeli, geçici çözümler olmamalıdır. Bu ihtiyaçtan hareketle temiz ve yenilenebilir enerji kaynaklarına yönelmeli, kamuoyunda iklim değişikliğine karşı bilinç oluşturacak faaliyetler düzenlenmelidir.

IPCC’nin 2500 yılına kadar olan projeksiyonlarının zamansal olarak dışında kalsa da antropojenik faktörlerin Dünya buzul varlığının tamamını erittiği farz edildiğinde; Antartika buzullarından 73, Grönland buzullarından 6, Alaska buzullarından 0.12 ve diğer buzulların erimesiyle birlikte toplam 80 metreyi bulacak bir deniz seviyesi yükselimi potansiyeli olduğu tahmin edilmektedir (URL 15). Sinop Yarımadası üzerindeki 6 metrelik deniz seviyesi yükselmesine bağlı olumsuz etkiler her ne kadar daha az tehditkâr gözükse de bu seviyede bir yükselmenin sonuçları kuşkusuz yarımada ve Dünya üzerinde yıkıcı bir etkiye sahip olacaktır.

Organize olamamış ve küreselleşememiş bir mücadele, bu gidișatı durdurmakta yetersiz kalacaktır, bu yüzden Sinop yarımadasında alınabilecek müstakil önlemlerden ziyade küresel çapta müşterek bir çaba gösterilmesi gerektirmektedir. Olumsuz etkileri ortadan kaldırmak için yapılan çalışmaların günümüzdeki haliyle yetersiz kalacağı unutulmamalıdır. Doğal sistemde hâlihazırda var olan değişikliğin antropojenik faaliyetlerle hızlanması durumunun doğaya zarar veren yaşam tarzımızın değişmesiyle bir nebze yavaşlatılması mümkündür. Bu açıdan bireysel tüketim alışkanlıklarımda yapacağımız değişiklikler küçümsenmemelidir. Lakin iklim değişikliği şüphecilerinin bu konudaki tavırlarının küresel çapta etkili bir önlem almamızı zorlaştırdığı açıktır. 


\section{KAYNAKLAR}

Akkan, E. (1975). Sinop Yarımadasının Jeomorfolojisi. Ankara: Ankara Üniversitesi Basımevi.

Aksay, C.S., Ketenoğlu, O. \& Kurt, L. (2005). Küresel ısınma ve iklim değişikliği. Selçuk Üniversitesi Fen Edebiyat Fakültesi Fen Dergisi, 25, 29-41.

Blainey, G. (2005). Dünya'nın Kısa Tarihi. (Çev: E. Kaliber \& O. Şen). (1. Baskı). İstanbul: 1001 Kitap.

Boden, T.A., Marland, G. \& Andres, R.J. (2017). 28 Ekim 2018 tarihinde cdiac.essdive.lbl.gov, adresinden edinilmiştir.

Boşgelmez, A. (2007). Küresel ısınma ve sonuçları. 21. Yüzyıl Dergisi, 3, 119-148.

Ceylan, M. A. (2011). Türkiye kıyılarında üzerinde şehir yerleşmesi bulunan tombololara genel bir bakış. Marmara Coğrafya Dergisi, 23, 352-372.

Erdoğan Sağlam N., Düzgüneş, E. \& Balık, i. (2008). Küresel ısınma ve iklim değişikliği. E.Ü. Su Ürünleri Dergisi, 25(1), 89-94.

Erinç, S. (2015). Jeomorfoloji II. İstanbul: Der Yayınları.

Erol, O. (2014). Genel Klimatoloji. İstanbul: Çantay Kitabevi.

Ertek, T.A. (2017). Antropojenik jeomorfoloji: konusu, kökeni ve amacı. Türk Coğrafya Dergisi, 69, 69-79.

Galip, A. (2006). Küresel ısınma, nedenleri ve sonuçları. Ankara Üniversitesi Dil ve Tarih-Coğrafya Fakültesi Dergisi 46(2), 29-43.

Gautier, C. (2014). Petrol, Su ve İklim. (Çev: S. Genç). (1. Baskı). Ankara: Tübitak Yayınları.

Geymen, A. \& Dirican, A.Y. (2016). İklim değişikliğine bağlı deniz seviyesi değişiminin coğrafi bilgi sistemleri kullanılarak analiz edilmesi, Harita Teknolojileri Elektronik Dergisi, 8, 95-74.

Gideş, E. (2018). Antropojenik jeomorfolojinin iklim değişikliğine etkileri. (Yüksek lisans tezi, İstanbul Üniversitesi, Sosyal Bilimler Enstitüsü, İstanbul). https://tez.yok.gov.tr/UlusalTezMerkezi/ adresinden edinilmiştir.

Gündoğan A. C., Sayman R. Ü., Baş, D., Arıkan, Y. \& Özsoy, G., (2015). A'dan Z'ye İklim Değișikliği Başucu Rehberi. Ankara: Bölgesel Çevre Merkezi - REC Türkiye.

Gürbüz, O. (2000) Sinop çevresindeki ekonomik faaliyetlerin esasları I. Coğrafya Dergisi, 8, 85-128. http://www.mta.gov.tr/v3.0/sayfalar/hizmetler/kutuphane/ekonomi-bultenleri/2014_18/b18_5560.pdf, adresinden edinilmiştir.

Huggett, R. J. (2015). Jeomorfolojinin Temelleri. (Çev-ed: U. Doğan.). Nobel Akademik Yayıncılık. Ilık Bilben, S. (2018). Antropojenik iklim değișikliği bağlamında göç tartışmaları. Sosyal Siyaset Konferansları Dergisi, 75, 237-268.

IPCC, (2013).

https://www.ipcc.ch/pdf/assessment-report/ar5/wg1/drafts/WG1AR5_SOD_Ch13_All_Final.pdf, (Son Erişim: 15.11.2018)

IPCC, (2018). https://www.ipcc.ch/sr15/, (Son Erişim: 15.11.2018) 
Antropojenik İklim Değișikliğine Bağlı Deniz Seviyesi Değișiminin Sinop Yarımadası'na Olası Etkileri Kaya, M. \& Yılmaz, C. (2017). (Yaşlı, mutlu, huzurlu il) Sinop'un nüfus özellikleri. Doğu Coğrafya Dergisi, 38, 137-160.

King, D. (2005). Climate change: the science and the policy. Journal of Applied Ecology, 42, 779-783.

Korkmaz, K. (2007). Küresel ısınma ve tarımsal uygulamalara etkisi. Alatarım Dergisi, 6, 43-49.

Lutgens,F., Tarbuck, E. \& Tasa, D.(2014). Genel Jeoloji Temel Kavramlar. (Çev-ed: C. Helvacı.). Nobel Akademik Yayıncılık.

Özdemir, M.A. (2004). İklim değişmeleri ve uygarlık üzerindeki yansımalarına ilişkin bazı örnekler. Sosyal Bilimler Dergisi, 2(6), 173-191.

Özey, R. (2014). Çevre Sorunları Coğrafyası. İstanbul: Aktif Yayınları.

Öztürk, M. Z., Çetinkaya, G. \& Aydın, S. (2017) Köppen-Geiger iklim sınıflandırmasına göre Türkiye’nin iklim tipleri. Coğrafya Dergisi, 35, 17-27.

Reuter H.I, Nelson A. \& Jarvis, A. (2007). An evaluation of void filling interpolation methods for SRTM data, International Journal of Geographic Information Science, 21:9, 983-1008.

Simav, Ö., Şeker, D.Z., Tanık, A. \& Gazioğlu C. (2015). Kıyı etkilenebilirlik göstergesi ile Türkiye kıyıları risk alanlarının tespiti. Harita Dergisi, 153, 1-8.

Şen, Ö. L., Bozkurt, D., Göktürk, O. M., Dündar, B., \& Altürk, B. (2013). Türkiye'de iklim değişikliği ve olası etkileri.

https://www.researchgate.net/profile/Bahadir_Altuerk/publication/322099836_Turkiye\%27de_Iklim_D egisikligi_ve_Olasi_Etkileri/links/5a44e280458515f6b0531a0e/Tuerkiyede-Iklim-Degisikligi-ve-OlasiEtkileri.pdf, (Son Erişim: 29.11.2018).

Şüküroğlu, H. E., (2018).

Tabiatikorumaalanlari/SarikumTKA.aspx?sflang=tr, (Son Erişim: 28.10.2018)

Türkeş M. (2008). Küresel iklim değişikliği nedir? Temel kavramlar, nedenleri, gözlenen ve öngörülen değişiklikler. İklim Değişikliği ve Çevre, 1, 26-37.

Türkeş, M., Sümer, U. M. \& Çetiner, G. (2000). Küresel İklim Değişikliği ve Olası Etkileri, Ankara: Çevre Bakanlığı, Birleşmiş Milletler İklim Değişikliği Çerçeve Sözleşmesi Seminer Notları.

Türkeş, M., Şen, Ö. L., Kurnaz, L., Madra, Ö., \& Şahin, M. (2013). İklim değişikliğinde son gelişmeler: IPCC 2013 raporu. Sabancı Üniversitesi, İstanbul Politikalar Merkezi.

URL 1, https://www.epa.gov/ghgemissions/global-greenhouse-gas-emissions-data, (Son Erișim: 23.10.2018)

URL 2, https://climate.nasa.gov/vital-signs/global-temperature/, (Son Erişim: 23.10.2018)

URL 3, https://www.nasa.gov/content/goddard/antarctic-sea-ice-reaches-new-record-maximum, (Son Erişim: 30.11.2018)

URL 4, https://www.scientificamerican.com/article/what-to-believe-in-antarctica-rsquo-s-great-icedebate/, (Son Erişim: 30.11.2018)

URL 5, https://www.theguardian.com/science/2016/mar/22/sea-level-rise-james-hansen-climatechange-scientist, (Son Erişim: 02.12.2018)

URL 6, http://bolge10.ormansu.gov.tr/10bolge/AnaSayfa/Korunan_Alanlarimiz/(Son Erişim: 04.12.2018) 
URL 7, https://www.mgm.gov.tr/ (Son Erişim: 15.11.2018)

URL 8, https http://www.sinop.gov.tr/cografya, (Son Erişim: 15.11.2018)

URL 9, https://sinop.dhmi.gov.tr/Sayfalar/default.aspx, (Son Erişim: 15.11.2018)

URL 10, https://www.kgm.gov.tr/Sayfalar/KGM/SiteTr/Root/default.aspx, (Son Erişim: 15.11.2018)

URL 11, Sinop İli, Merkez İlçesi, Yalıköy Mevkii, Kıyı Koruma Yapısı(Ayrık Dalgakıran) Amaçlı Nazım İmar Planı, https://sinop.csb.gov.tr/sinop-merkez-ilce-yalikoyu-mevkii-kiyi-koruma-yapisi-ayrik-dalgakiranamacli-imar-plani-duyuru-350957, (Son Erișim: 5.12.2018)

URL 12,

http://www.kugm.gov.tr/BLSM_WIYS/DLH/tr/DOKUMAN_SOL_MENU/Limanlar

/Tamamlanan_Projeler/20160908_063751_10288_1_84851.pdf, (Son Erişim: 05.11.2018)

URL 13,

http://www.aygm.gov.tr/BLSM_WIYS/DLH/tr/DOKUMAN_SOL_MENU/Limanlar/Tamamlanan_Projeler/2

0111123_154051_10288_1_46492.html, (Son Erişim: 05.12.2018)

URL 14, Zuiderzee floods, https://www.britannica.com/event/Zuiderzee-floods, (Son Erişim: 11.02.2019)

URL 15,

https://www.usgs.gov/faqs/how-would-sea-level-change-if-glaciers-melted?qt-

news_science_products=0\#qt-news_science_products, (Son Erişim: 02.12.2018)

Ülke, A. \& Özkoca, T. (2018). Sinop, Ordu ve Samsun illerinin sıcaklık verilerinde trend analizi. GÜFBED, 8(2), 455-463.

Ward, P.D. (2014). Yerküre Sulara Gömülürken, Buz Örtüleri Olmayan Bir Dünya'da Geleceğimiz. (Çev: E. Soğancılar). (2. Baskı). Ankara: Tübitak Yayınları.

Woodward, J. (2015). Yakından Tanıyın - İklim Değișimi. Ankara: Tübitak Yayınları.

Yıldız, H., Demir, C., Gürdal, M. A., Akabalı, O. A., Demirkol, E. O., Ayhan, M. E. (2003). Antalya-II, Bodrum-II, Erdek ve Menteş mareograf istasyonlarına ait 1984-2002 yılları arası deniz seviyesi ve jeodezik ölçülerin değerlendirilmesi. Harita Dergisi, 17, 1-75.

Yılmaz, C. (2005). "Sarıkum Gölü Ekosistemi (Sinop)”, TURQUA - Türkiye Kuvaterner Sempozyumu V, (0203 Haziran 2005), Bildiriler Kitabı, (Editörler: O. Tüysüz - M. K. Erturaç), İstanbul Teknik Üniversitesi, Avrasya Yerbilimleri Enstitüsü Yayını, (219-226), İstanbul. 